\title{
The effect of green supply chain practices on firm sustainability performance: Evidence from Pakistan
}

\author{
Adnan Sarwar ${ }^{a}$, Aqsa Zafar ${ }^{\mathrm{b}}$, Muhammad Ali Hamzaa and Alia Qadir
}

${ }^{a}$ Department of Economics and Business Management, University of Veterinary and Animal Sciences, Lahore, Pakistan ${ }^{b}$ Department of Management Science, Riphah International University, Faisalabad Campus, Pakistan

\section{H R O N I C L E}

Article history:

Received October 2, 2020

Received in revised format

November, 10, 2020

Accepted December 202020

Available online

December 202020

Keywords:

Green supply chain

management

Economic performance

Industrial performance of

Pakistan

\section{A B S T R A C T}

Environmental issues are most important among the current global concerns, and business activities are seen as a cause of significant threat to the environment due to environmentally nonfriendly practices by various industries that cause pollution. However, the implementation of green supply chain management (GSCM) practices in developing countries like Pakistan is still inconclusive. The purpose of this paper is to investigate the impact of GSCM dimensions on economic, environmental, and social performance. The five dimensions covered in this research are green purchasing, green manufacturing and remanufacturing, environmental education, internal environmental management, and investment recovery. A survey questionnaire was prepared that consists of green practices as well as a performance indicator. Factor analysis maximum likelihood method was used to examine the survey data of Pakistani organizations. The results of this study indicate that GSCM practices have a positive impact on environmental, economic, and social performance. This research shows organizations are aware of improving their performance while adopting green supply chain practices.

\section{Introduction}

The rapidly increasing green concerns in the ultimate customer markets, as well as the pressure from the government, compel the organizations to adopt an ecological perspective in their supply chain activities (Lin \& Ho, 2011). Besides the product's cost, quality, lead-time organizations need to improve environmental performance as a competitive priority. In the earlier, firms focused on implementing internal green practices to minimize pollution as well as lessen environmental impacts on their production. Recently, the firms have begun to implement external green practices such as green purchasing, eco-design due to environmental crises (Corbett, Klassen, \& Management, 2006). The green practices and environmental concerns within the supply chain management have become an important topic in academia. In the competitive world, sustainability becomes the challenging issue as a result of socio-economics and environmental problems caused by irresponsible or unethical business operations in the process of acquiring raw material, manufacturing, logistics, and disposal of products at the end of their useful life (Fornasiero et al., 2016). Green supply chain management is a new thought for today's organization to minimize degradation and the violation of human rights (Kirchoff, Tate, Mollenkopf, \& Management, 2016). Green supply chain management can be stated as the process of improving environmental performance along with supply chain practices: product design, operations management, and customer relationship. Supply chain management is the integration and coordination of business processes in the supply chain to satisfy the ultimate consumer (Pourjavad \& Shahin, 2018). The business process includes various phases: purchasing, manufacturing, marketing, logistics, and information systems. Business strategic imperative includes product quality, customer focus, efficiency, and responsiveness (Vanalle, Ganga, Godinho Filho, \& Lucato, 2017). The studies suggested that the consideration of green practices has a significant and positive impact on the organization's performance (Çankaya \& Sezen, 2019; Chan, He, Chan, \& Wang, 2012). Green supply chain management is similar to important concepts such as sustainable supply chain

* Corresponding author

E-mail address: adnansarwar@live.com (A. Sarwar)

C 2021 by the authors; licensee Growing Science. doi: $10.5267 /$ j.uscm.2020.12.004 
management that assist the firms to gain their objectives while minimizing the negative effects of the operation on the environment (Beske, Koplin, Seuring, \& Management, 2008). In literature, it has been shown green supply chain management is a key factor for a firm's sustainable development and competitiveness. Environmental management not only reduces the firm cost of production but also enables them to fulfill their social responsibility as well as environment-friendly activities. Manufacturing firms are the main culprit responsible for the environmental issues that lead to health and safety problems for the workers and the community (Ahmed \& Najmi, 2018; Beamon \& Mgmt, 1999).

The subject green supply chain management has been increasingly discussed and incorporated by the firms. The objective of these debates to identify the barriers, pressure, and motivation to adopt GSCM practices ( Eltayeb, Zailani, Ramayah, \& recycling, 2011). All over the world, industries are implementing GSCM techniques to minimize environmental pollution. The concept of GSCM is to induce environment thinking into supply chain activities (Çankaya \& Sezen, 2019; Eltayeb et al., 2011). In developed countries, the concept of GSCM is well-known and successfully implemented. In Pakistan, GSCM is new and its implementation is still at the initial phase. Social pressure and environmental constraints are forcing industries to implement GSCM practices as environmental pollution is a growing concern in Pakistan. In Pakistan, due to lack of research on GSCM and its effect on industrial performance is the reason why an only a small portion of the industry is implementing green practices. Thus, the objective of this research is to investigate the performance of industry after implementing green practices. For this research, the Pakistani organization implementing GSCM practices have been considered to measure the impact of GSCM on economics, environmental, and social performance. Further, in detail, five dimensions have been analyzed i.e. green purchasing, green manufacturing and remanufacturing, internal environmental management, environmental education, and investment recovery. The impact of the above dimensions has been determined by the social, economics, and environmental performance of the Pakistani industry (Grimm, Hofstetter, \& Sarkis, 2014) stated, it is the reality the implementation of GSCM practices has numerous difficulties, while it enables the organization to increase profitability and eliminate environmental pollution. It provides new opportunities that can help to compete and add new values in the business. Unfortunately, research on this issue in Pakistan is still immature. With the implementation of GSCM practices, organizations can choose from a variety of suppliers and reduce the environmental impacts on the entire supply chain activities. It brings new thought in the business and enables to compete in the market (Ahmed et al., 2020).

\section{Literature Review and Hypothesis}

Industrialization plays a prominent role in the economic success of a county as well as it is also the responsibility of the industry to minimize the negative impact on the environment. In this context, GSCM enables the industry to increase profit while overcoming environmental issues. GSCM is a process to integrate environmental thinking into the supply chain, including, green design, green purchasing, green manufacturing, green distribution, logistics, marketing, and reverse logistics (Sarkis, Gonzalez-Torre, \& Adenso-Diaz, 2010). The concept of Green supply chain management covers all sets of practices include supply chain management and environmental management. Thus, GSCM practices are extremely important.

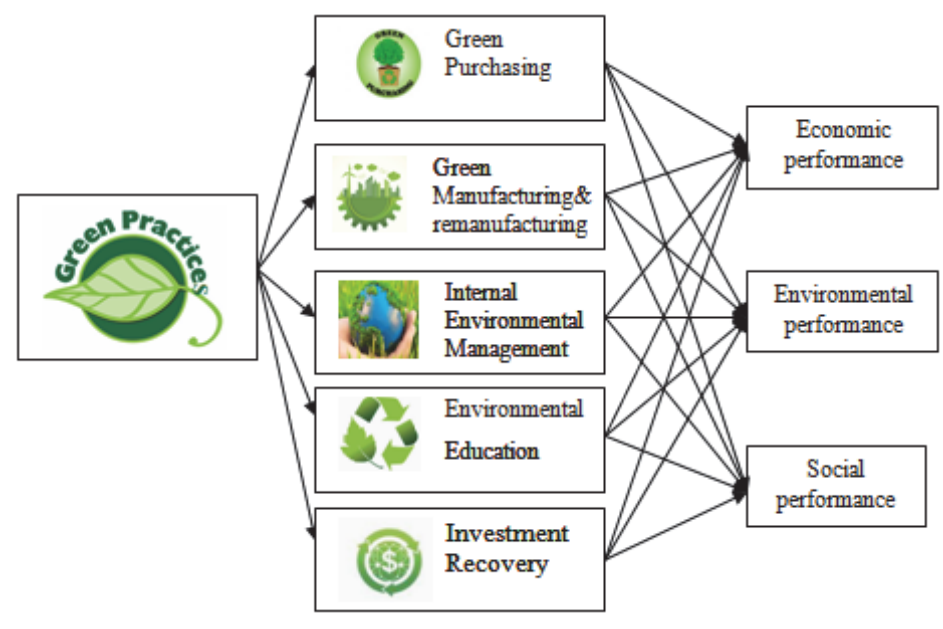

Fig. 1. Research framework and hypothesis

In this research, various five GSCM practices identified (green purchasing, green manufacturing and remanufacturing, internal environmental management, environmental education, investment recovery) and objective to explore the influence of these practices on environmental, economic, and social performance. These GSCM measurements are briefly defined based on the literatre (Bu, Dang, Wang, Liu, \& Health, 2020; Chan et al., 2012; Choi, Min, Joo, Choi, \& Applications, 2017; Das, 2018; Mutingi, Mapfaira, \& Monageng, 2014; Xie \& Breen, 2012' Sammalisto \& Brorson, 2008) as follows: 
Table 1

Independent Variables

\begin{tabular}{|c|c|c|}
\hline Factors & Dimensions & Description \\
\hline \multirow{5}{*}{ Green purchasing } & GP1 & Providing design specification to suppliers which include an environmental requirement for purchase items \\
\hline & GP2 & $\begin{array}{l}\text { Ensure that the purchased product does not contain environmentally unacceptable substances such as lead } \\
\text { and other harmful or hazardous materials. }\end{array}$ \\
\hline & GP3 & Consideration of suppliers having ISO 14001 certification \\
\hline & GP4 & Environmental assessment for the supplier's internal management. \\
\hline & GP5 & Suppliers are required to utilize environmental packaging: i.e. degradable and non-hazardous. \\
\hline \multirow{6}{*}{$\begin{array}{l}\text { Green manufacturing } \\
\text { and remanufacturing }\end{array}$} & GM1 & Monitor and control environmental pollution such as drain emission \\
\hline & GM2 & Reduce noise pollution during the manufacturing process. \\
\hline & GM3 & Controlling hazardous substances in the manufacturing process and exploitation of the available resources. \\
\hline & GM4 & Process design focuses on minimizing the consumption of energy and natural resources in operations \\
\hline & GM5 & $\begin{array}{l}\text { Recycling and reuse/recover valuable materials and components in the field of product design after the end } \\
\text { of theirs. }\end{array}$ \\
\hline & GM6 & $\begin{array}{l}\text { Emphasizes the proactive and preventative maintenance to increase the operational efficiency of the } \\
\text { equipment }\end{array}$ \\
\hline \multirow{5}{*}{$\begin{array}{l}\text { Internal environmental } \\
\text { management }\end{array}$} & IEM1 & The commitment of GSCM from senior managers \\
\hline & IEM2 & Support from mid-level managers for GSCM \\
\hline & IEM3 & Cross-functional collaboration to attain environmental improvements \\
\hline & IEM4 & Conduct a seminar for awareness of the environment. \\
\hline & IEM5 & Creation of environmental reports for internal assessment. \\
\hline \multirow{4}{*}{$\begin{array}{l}\text { Environmental } \\
\text { education }\end{array}$} & EE1 & Environmental awareness seminar for suppliers \\
\hline & EE2 & Natural environmental seminars for executives/top management \\
\hline & EE3 & Environmental training and education programs for managers and employees \\
\hline & EE4 & Participation in government-subsidized natural environmental programs \\
\hline \multirow{5}{*}{ Investment recovery } & IR1 & Investment recovery (sale) of excess inventories/materials \\
\hline & IR2 & Establishing a recycling system for used and defective products \\
\hline & IR3 & Sales of scrap and used materials. \\
\hline & IR4 & Sales of excess capital equipment. \\
\hline & IR5 & Collecting and recycling end of life products and materials \\
\hline
\end{tabular}

Moreover, the dependent variables are defined according to (Das, 2018; Laari, Töyli, Solakivi, \& Ojala, 2016; Mutingi et al., 2014; Qorri, Mujkić, Gashi, \& Kraslawski, 2018) as follows,

Table 2

Dependent variables

\begin{tabular}{lll}
\hline Factor & Dimension & Description \\
\hline \multirow{3}{*}{ Economic performance } & EP1 & Lower/Minimize the cost of purchase material \\
& EP2 & Lower/ Minimize the cost of energy consumption \\
& EP3 & The decrease in treatment and waste expulsion costs \\
& EP4 & Reduction of penalty for violating environmental laws \\
& EP5 & Reduction of waste disposal costs \\
\hline \multirow{3}{*}{ Social performance } & SP1 & Employee's health and safety workplace \\
& SP2 & Contribution to social investments projects (education, culture, sports) \\
& SP3 & Enhance community health and safety \\
& SP4 & Reducing the adverse impact of products and process on the local community \\
\hline \multirow{3}{*}{ Environmental performance } & EP1 & Reduce the discharge of noxious chemicals into the air and water \\
& EP2 & Reduction in wastage and recycling of materials in the manufacturing process \\
& EP3 & Enhancement of company's environmental position \\
& EP4 & Decrease the frequency of environmental accidents/mishaps \\
& EP5 & Lower the consumption of harmful/toxic/hazardous material. \\
\hline
\end{tabular}

- Green purchasing: Green purchasing is also called Environmentally Preferable Purchasing. It may be defined as integrating environmental concerns in procurement (Mutingi et al., 2014; Younis, Sundarakani, \& Vel, 2016). The objective of green purchasing is to ensure that procured material has a positive environmental impact such as the absence of hazardous material (Carter, Kale, Grimm, \& Review, 2000). The selection of optimal suppliers plays a dynamic role in an organization's environmental performance. It is also important to examine that the supplier meets the green criteria of the organization (Bu et al., 2020).

- Green manufacturing and remanufacturing: Green manufacturing and remanufacturing is one of the most dimension of GSCM. The purpose of green manufacturing and remanufacturing is to improve the industrial processes and products to minimize soil, water, and air pollution (Das, 2018). Furthermore, it is beneficial to reduce cost, scrap rate, wastage, maximize product efficiency, reuse, recycle, and positive environmental impact on supply chain activities. In the nutshell, it aims to produce eco-friendly products with minimum utilization of resources (material, energy, and water) (Rajeev, Pati, Padhi, \& Govindan, 2017).

- Internal environmental management: Internal environmental management is a company's own environmental protection policies. It is a strategic organizational commitment and support from upper, mid-level managers and departmental cooperation for setting up an environmental improvement (Chan et al., 2012). It develops an environmental management system to deal with environmental issues (Xie \& Breen, 2012). 
- Environmental education: Environmental education is an important tool to ensure the development of a sustainable society and human resources (Routroy, 2009). The studies emphasized environmental education is very important for companies to be successful. It aims to demonstrate the employees the environmental policies of the organization (Choi et al., 2017).

Investment Recovery: It is a traditional firm's practice where excess material/inventories or scraped material and excess capital equipment are resold (Xie \& Breen, 2012). It is a green dimension to get the highest benefits from the existing investment that was considered as wastage. The purpose of investment recovery is to recover maximum value from the end life cycle and obsolete (Ayres, Ferrer, \& Van Leynseele, 1997).

\subsection{GSCM practices and environmental performance}

This dimension relates to the environmental impact on firm activities. Past research shows a perception of the positive relationship between GSCM practices and environmental performance (Beamon, 1999). The implementation of green practices has reduced environmental accidents (material, waste production, liquid waste) and improved organization performance and society health (Das, 2018). A firm needs to identify environmental issues such as procurement, manufacturing, and transportation (Azevedo, Carvalho, Machado, \& review, 2011). The firm utilizes minimum resources and reasons for environmental pollution through interfering hazardous waste, soil, air, and water. Environmental performance ensures the firm ability to reduce hazardous substances, pollution, environment accidents and solid waste (Esfahbodi, Zhang, \& Watson, 2016). The following hypotheses are proposed:

$\mathrm{H}_{1 \mathrm{a}}$ : Green purchasing has a positive relationship with environmental performance.

$\mathrm{H}_{1 \mathrm{~b}}$ : Green manufacturing and remanufacturing have a positive relation with environmental performance.

$\mathrm{H}_{1 \mathrm{c}}$ : Internal environmental management has a positive relationship with environmental performance.

$\mathrm{H}_{1 \mathrm{~d}}$ : Environmental education has a positive relationship with environmental performance.

$\mathrm{H}_{1 \mathrm{e}}$ : Investment recovery has a positive relationship with environmental performance.

\subsection{GSCM practices and economic performance}

Economic performance is concerned about the firm's manufacturing ability to cut down the costs related to material, water treatment, energy consumption, waste discharge, and lesser environmental accident (Micheli, Cagno, Mustillo, \& Trianni, 2020). In this dimension, sales and profitability are considered. (Mutingi et al., 2014) stated that green practices improved the economic performance in an organization. While other proposed that GSCM practices have no positive impact on an organization in the short-term means sales and profitability performance. It is also stated that green purchases increase the product cost which negatively affects financial performance (Cousins, Lawson, Petersen, Fugate, \& Management, 2019). NRBV states the implementation of green practices enables an organization to achieve economic benefit by reducing energy cost, wastage, and increasing corporate reputation and loyalty. Therefore, the hypothesize that:

$\mathrm{H}_{2 \mathrm{a}}$ : Green purchasing has a positive relationship with economic performance.

$\mathrm{H}_{2 \mathrm{~b}}$ : Green manufacturing and remanufacturing have a positive relation with economic performance.

$\mathrm{H}_{2 \mathrm{c}}$ : Internal environmental management has a positive relationship with economic performance.

$\mathrm{H}_{2 \mathrm{~d}}$ : Environmental education has a positive relationship with economic performance.

$\mathrm{H}_{2 \mathrm{e}}$ : Investment recovery has a positive relationship with economic performance.

\subsection{GSCM practices and social performance}

Social performance means an organized set of principles and policies of GSCM to improve organization image, protection worker's safety, health, as well as ensure customer satisfaction and loyalty. However, in the GSCM topic, social performance generally was ignored. It is important to raise awareness on corporate social responsibility that is equally significant in social issues while managing supply chain activities (Cousins et al., 2019). It will increase the positive image in the eyes of the government, society, stakeholders, and customers. (Laari et al., 2016) stated that GSCM makes it possible for the organization to improve brand image and build up a strong relationship with the stakeholder. Therefore, the hypothesize that:

$\mathrm{H}_{3 \mathrm{a}}$ : Green purchasing has a positive relationship with social performance.

$\mathrm{H}_{3 b}$ : Green manufacturing and remanufacturing have a positive relationship with social performance.

$\mathrm{H}_{3 \mathrm{c}}$ : Internal environmental management has a positive relationship with social performance.

$\mathrm{H}_{3 \mathrm{~d}}$ : Environmental education has a positive relationship with social performance.

$\mathrm{H}_{3 \mathrm{e}}$ : Investment recovery has a positive relationship with social performance.

\section{Material and Method}

\subsection{Construction of instrument and measure}

In this research Pakistani firms are considered to investigate how green practices are implemented. Due to pollution and climate change in the country, the policies regarding GSCM practices are an important part of the industry. Before the development of the questionnaire, three academicians and 10 supply chain managers were asked which dimensions of GSCM practices should be considered. As a result of these practitioners, five dimensions are considered to be analyzed. 
These GSCM practices were: green purchasing, green manufacturing and remanufacturing, internal environmental management, environmental education, and investment recovery. These five practices are further divided into 25 items. These practices are addressed according to the current literature of GSCM dimensions (Beamon \& Mgmt, 1999; Bu et al., 2020; Xie \& Breen, 2012). Three performance indicators are determined as economic, environmental, and social performance. A questionnaire was developed based on the relevant literature to measure GSCM dimensions. The questionnaire was sent to the individual who had at least a bachelor's degree. It consists of supply chain managers, plant managers, logistics managers, purchasing managers, operations managers, and manufacturing managers. Data were collected through direct survey methods due to unawareness of green practices in Pakistan. One hundred and forty-five questionnaires were considered for analysis of results. Factor analysis maximum likelihood method was developed to confirm the grouping of collected data and linear regression was used to analyze the hypothesis.

\subsection{Factor Analysis}

Factor analysis was conducted to measure overall green practices by using IBM SPSS Statistics Software to further confirm the grouping of GSCM practices from the survey data. Factors are extracted using the maximum likelihood method, followed by varimax rotation. Kaiser criterion (Eigenvalue $>1$ ) is used. It identifies the number of various factors to retain and get a sensible variance. Factor analysis was developed for both variables (independent and dependent). Five factors are identified for the rotation of independent variables and three for the dependent variables.

\section{Results and discussions}

\subsection{Independent variables}

Factor analysis was executed to determined GSCM practices (Independent variables) using the method of maximum likelihood analysis with varimax rotation. Five factors were extracted, and the total variance extracted also presented in Table 3.

Table 3

The total variance of GSCM practices

\begin{tabular}{|c|c|c|c|c|c|c|c|c|c|}
\hline \multirow[t]{2}{*}{ Factor } & \multicolumn{3}{|c|}{ Initial Eigenvalues } & \multicolumn{3}{|c|}{ Extraction Sums of Squared Loadings } & \multicolumn{3}{|c|}{ Rotation Sums of Squared Loadings } \\
\hline & Total & $\begin{array}{l}\% \text { of } \\
\text { Variance }\end{array}$ & Cumulative \% & Total & $\begin{array}{l}\% \text { of } \\
\text { Variance }\end{array}$ & Cumulative $\%$ & Total & $\begin{array}{l}\% \text { of } \\
\text { Variance }\end{array}$ & Cumulative $\%$ \\
\hline 1 & 5.560 & 22.241 & 22.241 & 2.970 & 11.881 & 11.881 & 4.522 & 18.088 & 18.088 \\
\hline 2 & 3.801 & 15.205 & 37.446 & 3.447 & 13.788 & 25.668 & 2.528 & 10.110 & 28.198 \\
\hline 3 & 2.916 & 11.663 & 49.109 & 3.207 & 12.826 & 38.495 & 2.516 & 10.064 & 38.261 \\
\hline 4 & 1.990 & 7.959 & 57.068 & 2.249 & 8.996 & 47.490 & 2.268 & 9.074 & 47.335 \\
\hline 5 & 1.104 & 4.415 & 61.483 & 1.206 & 4.824 & 52.314 & 1.245 & 4.979 & 52.314 \\
\hline
\end{tabular}

As displayed in Table 3 Kaiser Criterion (Eigenvalue $>1$ ) is satisfied by five-factor. These five factors contribute $61.483 \%$ of the total variance. Fig. 2 rotated factor matrix represents the correlation between variables and their factors. Research results demonstrated that GP2, GP3, GP4, and GP5 have strongly correlated with factor 1 than other factors, therefore factor 1 shows the variable of green practices. Factor 2 indicates the environmental education variable, EE1, EE2, EE3, and EE4 have strongly correlated with factor 2 . So, besides, factor 3 represents the investment recovery variable because IR1, IR2, IR3, and IR4 have a strong correlation with factor 3. Factor 4 indicates internal environmental management and factor 5 have a strong relationship with green manufacturing and remanufacturing. Additionally, Cronbach's alpha of these five factors is $0.84,0.844,0.759,0.810$, and 0.805 respectively, as shown in fig. 2 indicates that the construct chosen for the study is reliable.

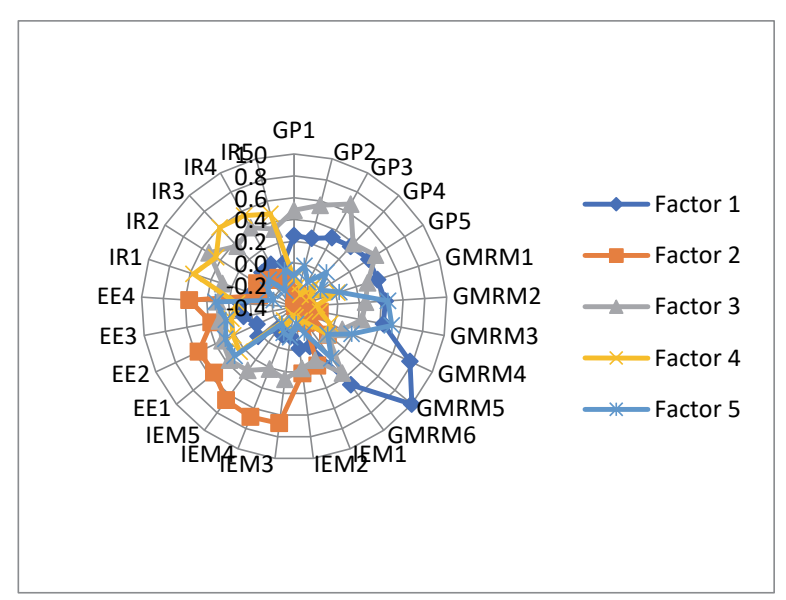

Fig. 2. Rotated factor matrix (varimax rotation)

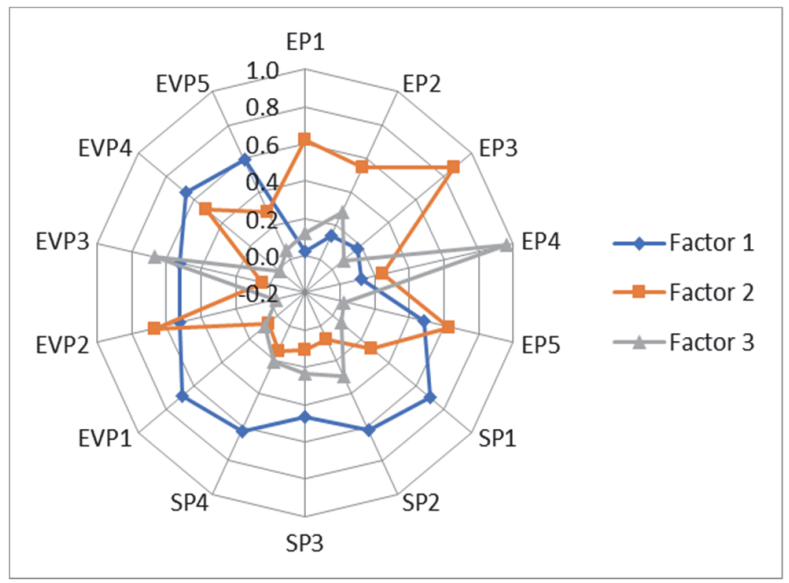

Fig. 3. Rotated Factor Matrix (varimax rotation) 


\subsection{Dependent variables}

The performance indicators (dependent variables) of an organization are shown in Table 3. These items present the performance of firms. Factor analysis was conducted to determined GSCM performance (dependent variables) using the method of maximum likelihood analysis with varimax rotation. Three factors were extracted for GSCM performance. Table 4 reveals that maximum likelihood extracted three factors for GSCM performance with Eigen values $>1$. These three factors explain $66.144 \%$ of the variance in data.

Table 4

The total variance of performance indicator

\begin{tabular}{|c|c|c|c|c|c|c|c|c|c|}
\hline \multirow[t]{2}{*}{ Factor } & \multicolumn{3}{|c|}{ Initial Eigenvalues } & \multicolumn{3}{|c|}{ Extraction Sums of Squared Loadings } & \multicolumn{3}{|c|}{ Rotation Sums of Squared Loadings } \\
\hline & Total & $\%$ of Variance & Cumulative $\%$ & Total & $\%$ of Variance & Cumulative \% & Total & $\%$ of Variance & Cumulative $\%$ \\
\hline 1 & 5.962 & 42.588 & 42.588 & 2.476 & 17.688 & 17.688 & 3.593 & 25.667 & 25.667 \\
\hline 2 & 1.843 & 13.164 & 55.752 & 4.231 & 30.221 & 47.909 & 2.829 & 20.208 & 45.874 \\
\hline 3 & 1.455 & 10.392 & 66.144 & 1.384 & 9.883 & 57.793 & 1.669 & 11.918 & 57.793 \\
\hline
\end{tabular}

Fig. 3 rotated matrix represents the correlation between performance indicators of GSCM performance. The result points out that SP1, SP2, and SP4 confirm strong correlations with factor 1; therefore factor 1 represents the social performance. Similarly, Economic performance and environmental performance have strong correlations with factors 2 or 3 as shown in Fig 2.

\subsection{Regression analysis}

After determining GSCM practices and performance regression analysis is used to test the proposed hypothesis to verify the relationship between the independent and dependent variables.

\subsubsection{Environmental performance}

Table 5 presents the result of 1st proposed hypothesis regarding Environmental performance how the implementation of GSCM practices influences environmental performance. Proposed Hypothesis 1a, 1b, 1c, 1d, and 1e hypothesize implementation of GSCM practices has a positive effect on environmental performance. Table 5 shows that the all GSCM practices have a significant positive influence on Environmental performance because all dimensions P-value is less than 0.05 with a positive beta value of Green purchasing 0.290 , Green manufacturing and Remanufacturing 0.305 Internal environmental management 0.148 Environmental education 0.173 , and Investment recovery 0.210 . The result of this study found that the proposed hypotheses $1 \mathrm{a}, 1 \mathrm{~b}, 1 \mathrm{c}, 1 \mathrm{~d}$, and 1e are supported. Therefore, organizations can increase their environmental performance by increasing these practices.

Table 5

$\underline{\text { Regression analysis of environmental performance }}$

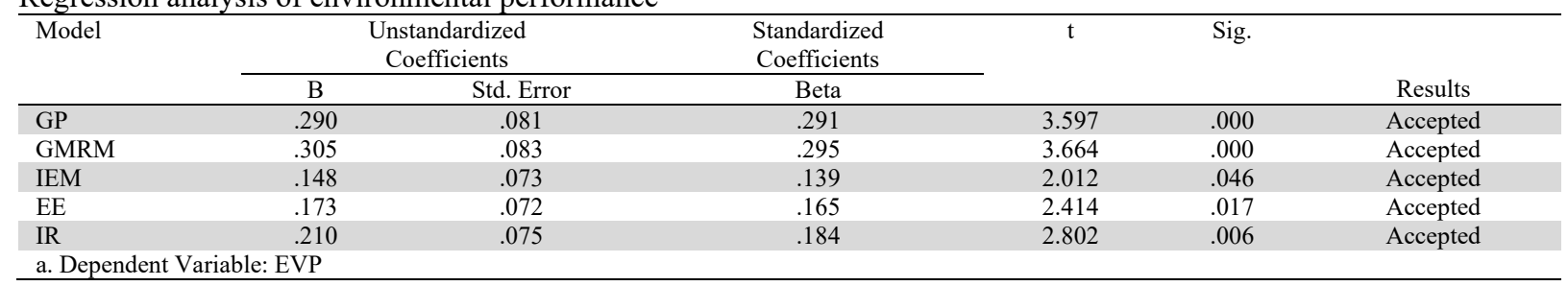

\subsubsection{Economic performance}

Economic performance is considered the second variable of performance. According to the proposed hypothesis, GSCM practices positively influence on economic performance. Therefore, proposed Hypotheses $2 \mathrm{a}, 2 \mathrm{~b}, 2 \mathrm{c}, 2 \mathrm{~d}$, and $2 \mathrm{e}$ hypothesize the implementation of GSCM practices has a positive effect on economic performance. Table 6 result shows that P-value $0.00,0.00$, and 0.001 which is less than 0.05 of Green purchasing, Green manufacturing \& remanufacturing, and Environmental education is highly significant with a positive beta value of $0.396,0.406$, and 0.208 . Therefore, hypothesis $2 \mathrm{a}, 2 \mathrm{~b}, 2 \mathrm{~d}$ are supported for this particular GSCM practices. Internal environmental management and Investment recovery have a negative beta for economic performance. Therefore, the proposed hypothesis $2 \mathrm{c}$ and $2 \mathrm{e}$ are rejected for this particular GSCM practices. Table 7 presents the result for implementation of GSCM practices on social performance proposed Hypothesis 3a, 3b, 3c, 3d, and 3e hypothesize implementation of GSCM practices have a positive influence on social performance Table 7 results show that the beta value of Green purchasing 0.276 , Green manufacturing and Remanufacturing 0.322, internal environmental management 0.193 and Environmental education 0.250 indicates a positive correlation with social performance. The P-value of Green purchasing is 0.001 , Green manufacturing 0.000 , internal environmental management 0.013, and Environmental education is 0.001 which is less than 0.05 , therefore the hypothesis $3 \mathrm{a}, 3 \mathrm{~b}, 3 \mathrm{c}, 3 \mathrm{~d}$ are accepted. Finally, positive beta value 0.116 demonstrated that Investment recovery positively correlated with social performance, and P-value 0.141 which is greater than 0.05 hence hypothesis $3 \mathrm{e}$ is not supported. 
Table 6

Regression Analysis of economics performance

\begin{tabular}{|c|c|c|c|c|c|c|}
\hline \multirow[t]{2}{*}{ Model } & \multicolumn{2}{|c|}{$\begin{array}{l}\text { Unstandardized } \\
\text { Coefficients }\end{array}$} & \multirow{2}{*}{$\begin{array}{c}\text { Standardized } \\
\text { Coefficients } \\
\text { Beta } \\
\end{array}$} & \multirow[t]{2}{*}{$\mathrm{t}$} & \multirow[t]{2}{*}{ Sig. } & \multirow[b]{2}{*}{ Results } \\
\hline & $\mathrm{B}$ & Std. Error & & & & \\
\hline GP & .290 & .081 & .291 & 3.597 & .000 & Accepted \\
\hline GMRM & .305 & .083 & .295 & 3.664 & .000 & Accepted \\
\hline IEM & .148 & .073 & .139 & 2.012 & .046 & Accepted \\
\hline EE & .173 & .072 & .165 & 2.414 & .017 & Accepted \\
\hline IR & .210 & .075 & .184 & 2.802 & .006 & Accepted \\
\hline
\end{tabular}

\subsubsection{Social performance}

Table 7

Regression analysis of social performance

\begin{tabular}{|c|c|c|c|c|c|c|}
\hline \multirow[t]{2}{*}{ Model } & \multicolumn{2}{|c|}{$\begin{array}{c}\text { Unstandardized } \\
\text { Coefficients }\end{array}$} & \multirow{2}{*}{$\begin{array}{c}\begin{array}{c}\text { Standardized } \\
\text { Coefficients }\end{array} \\
\text { Beta } \\
\end{array}$} & \multirow[t]{2}{*}{$\mathrm{t}$} & \multirow[t]{2}{*}{ Sig. } & \multirow[b]{2}{*}{ Results } \\
\hline & $\mathrm{B}$ & Std. Error & & & & \\
\hline GP & .276 & .084 & .268 & 3.274 & .001 & Accepted \\
\hline GMRM & .322 & .087 & .300 & 3.684 & .000 & Accepted \\
\hline IEM & .193 & .077 & .175 & 2.510 & .013 & Accepted \\
\hline $\mathrm{EE}$ & .250 & .075 & .231 & 3.329 & .001 & Accepted \\
\hline IR & .116 & .078 & .098 & 1.479 & .141 & Rejected \\
\hline
\end{tabular}

Dependent Variable: SP

\section{Conclusions}

In a developing country, the objective of industrial is to improve their economic performance while considering environmental sustainability. Implementation of GSCM practices in an organization is a relatively new concept in Pakistan. This research has contributed to investigate the relationship between GSCM practices and the organization's sustainability performance. GSCM practices on the three performance indicators (economics, social, and environmental) are analyzed. These appropriate green practices will enable the organization to strengthen the performance. The industrial sector is shaky to implement green practices. The findings of this research show that implementation of all green supply chain management practices has a significant positive impact on environmental performance and lead to environmental improvement. However, GSCM dimensions are also affecting positively on social performance. In this study, only three of five GSCM dimensions were correlated with economic performance. It may be due to the reason that the initiative of GSCM has usually required huge investment which may negatively impact on Pakistani organization because of newly implementing green practices. The results of this study will motivate the organization to implement green practices that can minimize environmental pollution, cost-effective, and improve social performance as well.

\section{Acknowledgments}

We would like to thank the editors as well as the reviewers who have generously given up valuable time to review paper. Their conscientiousness is much appreciated.

\section{References}

Ahmed, W., Ashraf, M. S., Khan, S. A., Kusi-Sarpong, S., Arhin, F. K., Kusi-Sarpong, H., \& Najmi, A. (2020). Analyzing the impact of environmental collaboration among supply chain stakeholders on a firm's sustainable performance. Operations Management Research, 1-18.

Ahmed, W., \& Najmi, A. (2018). Developing and analyzing framework for understanding the effects of GSCM on green and economic performance. Management of Environmental Quality: An International Journal, 29(4), 740-758.

Ayres, R., Ferrer, G., \& Van Leynseele, T. (1997). Eco-efficiency, asset recovery and remanufacturing. European Management Journal, 15(5), 557-574.

Azevedo, S. G., Carvalho, H., \& Machado, V. C. (2011). The influence of green practices on supply chain performance: A case study approach. Transportation Research Part E: logistics and Transportation Review, 47(6), 850-871.

Beamon, B. M. (1999). Designing the green supply chain. Logistics Information Mgmtement, 12(4), 332-342.

Beamon, B. M. (1999). Measuring supply chain performance. International Journal of Operations \& Production Management, 19(3), 275-292.

Beske, P., Koplin, J., \& Seuring, S. (2008). The use of environmental and social standards by German first-tier suppliers of the Volkswagen AG. Corporate Social Responsibility and Environmental Management, 15(2), 63-75.

Bu, X., Dang, W. V., Wang, J., \& Liu, Q. (2020). Environmental orientation, green supply chain management, and firm performance: Empirical evidence from Chinese Small and medium-sized enterprises. International Journal of Environmental Research and Public Health, 17(4), 1199.

Çankaya, S. Y., \& Sezen, B. (2019). Effects of green supply chain management practices on sustainability performance. Journal of Manufacturing Technology Management, 30(1), 98-121. 
Carter, C. R., Kale, R., \& Grimm, C. M. (2000). Environmental purchasing and firm performance: an empirical investigation. Transportation Research Part E: Logistics and Transportation Review, 36(3), 219-228.

Chan, R. Y., He, H., Chan, H. K., \& Wang, W. Y. (2012). Environmental orientation and corporate performance: The mediation mechanism of green supply chain management and moderating effect of competitive intensity. Industrial Marketing Management, 41(4), 621-630.

Choi, S. B., Min, H., Joo, H. Y., \& Choi, H. B. (2017). Assessing the impact of green supply chain practices on firm performance in the Korean manufacturing industry. International Journal of Logistics Research and Applications, 20(2), 129-145.

Corbett, C. J., \& Klassen, R. D. (2006). Extending the horizons: environmental excellence as key to improving operations. Manufacturing \& Service Operations Management, 8(1), 5-22.

Cousins, P. D., Lawson, B., Petersen, K. J., \& Fugate, B. (2019). Investigating green supply chain management practices and performance. International Journal of Operations \& Production Management, 39(5), 767-786.

Das, D. (2018). The impact of Sustainable Supply Chain Management practices on firm performance: Lessons from Indian organizations. Journal of Cleaner Production, 203, 179-196.

Eltayeb, T. K., Zailani, S., \& Ramayah, T. (2011). Green supply chain initiatives among certified companies in Malaysia and environmental sustainability: Investigating the outcomes. Resources, Conservation and Recycling, 55(5), $495-506$.

Esfahbodi, A., Zhang, Y., \& Watson, G. (2016). Sustainable supply chain management in emerging economies: Trade-offs between environmental and cost performance. International Journal of Production Economics, 181, 350-366.

Fornasiero, R., Zangiacomi, A., Franchini, V., Bastos, J., Azevedo, A., \& Vinelli, A. (2016). Implementation of customisation strategies in collaborative networks through an innovative Reference Framework. Production Planning \& Control, 27(14), 1158-1170.

Grimm, J. H., Hofstetter, J. S., \& Sarkis, J. (2014). Critical factors for sub-supplier management: A sustainable food supply chains perspective. International Journal of Production Economics, 152, 159-173.

Kirchoff, J. F., Tate, W. L., \& Mollenkopf, D. A. (2016). The impact of strategic organizational orientations on green supply chain management and firm performance. International Journal of Physical Distribution \& Logistics Management, 46(3), 269-292.

Laari, S., Töyli, J., Solakivi, T., \& Ojala, L. (2016). Firm performance and customer-driven green supply chain management. Journal of Cleaner Production, 112, 1960-1970.

Lin, C. Y., \& Ho, Y. H. (2011). Determinants of green practice adoption for logistics companies in China. Journal of Business Ethics, 98(1), 67-83.

Micheli, G. J., Cagno, E., Mustillo, G., \& Trianni, A. (2020). Green supply chain management drivers, practices and performance: A comprehensive study on the moderators. Journal of Cleaner Production, 121024.

Mutingi, M., Mapfaira, H., \& Monageng, R. (2014). Developing performance management systems for the green supply chain. Journal of Remanufacturing, 4(1), 6.

Pourjavad, E., \& Shahin, A. (2018). The application of Mamdani fuzzy inference system in evaluating green supply chain management performance. International Journal of Fuzzy Systems, 20(3), 901-912.

Qorri, A., Mujkić, Z., Gashi, S., \& Kraslawski, A. (2018). Green supply chain management practices and company performance: A meta-analysis approach. Procedia Manufacturing, 17, 317-325.

Rajeev, A., Pati, R. K., Padhi, S. S., \& Govindan, K. (2017). Evolution of sustainability in supply chain management: A literature review. Journal of Cleaner Production, 162, 299-314.

Routroy, S. R. I. K. A. N. T. A. (2009). Antecedents and drivers for green supply chain management implementation in manufacturing environment. ICFAI Journal of Supply Chain Management, 6(1), 20-35.

Sammalisto, K., \& Brorson, T. (2008). Training and communication in the implementation of environmental management systems (ISO 14001): a case study at the University of Gävle, Sweden. Journal of Cleaner Production, 16(3), $299-309$.

Sarkis, J., Gonzalez-Torre, P., \& Adenso-Diaz, B. (2010). Stakeholder pressure and the adoption of environmental practices: The mediating effect of training. Journal of Operations Management, 28(2), 163-176.

Vanalle, R. M., Ganga, G. M. D., Godinho Filho, M., \& Lucato, W. C. (2017). Green supply chain management: An investigation of pressures, practices, and performance within the Brazilian automotive supply chain. Journal of Cleaner Production, 151, 250-259.

Xie, Y., \& Breen, L. (2012). Greening community pharmaceutical supply chain in UK: a cross boundary approach. Supply Chain Management: An International Journal, 17(1), 40-53.

Younis, H., Sundarakani, B., \& Vel, P. (2016). The impact of implementing green supply chain management practices on corporate performance. Competitiveness Review, 26(3), 216-245.

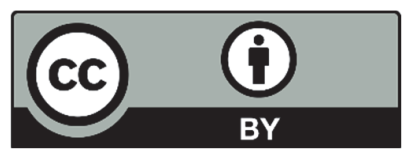

(C) 2021 by the authors; licensee Growing Science, Canada. This is an open access article distributed under the terms and conditions of the Creative Commons Attribution (CC-BY) license (http://creativecommons.org/licenses/by/4.0/). 